\title{
Telemeterized Indicator
}

National Cancer Institute

\section{Source}

National Cancer Institute. Telemeterized Indicator. NCI Thesaurus. Code C158350.

An indication as to whether the subject was telemeterized during the treatment or assessment. 